heeft het wel steeds een voorname plaats ingenomen in de rij van Hollandse, cultuurdragende steden, met als absolute hoogtepunt de zestiende en zeventiende eeuw. De onderliggende toon van het hele boek is deze verworvenheden te benadrukken; op bladzijde 46 (dertiende eeuw) gaat het zelfs over 'de toen al zelfbewuste bevolking, die aan de boorden van het Spaarne woonde'. Hedendaagse Haarlemse schrijvers wordt het soms openlijk verweten wel erg cynisch en negatief over deze prachtige stad te zijn. Een opmerking over Louis Ferron: 'Kennelijk verschaft het centrum hem zoveel vermaak dat hij daar al decennia woont, anderzijds kan de stad in zijn romans niet veel goed doen' (569).

Deze onschuldige vorm van bovenmatig enthousiasme wordt geheel vergoed door de mooie verhalen over Haarlemmers die een opmerkelijke plaats in de stad innamen, over de verschillende sociale klassen, over politieke verhoudingen, die niet zelden met religie verweven waren, en culturele ontwikkelingen. Hoewel Haarlem in veel van deze ontwikkelingen natuurlijk niet uniek was - over veel Hollandse steden is een soortgelijke geschiedenis te schrijven - wordt nauwkeurig de hand gehouden aan hoofdzakelijk Haarlemse thema's, politici, geestelijken en kunstenaars, zonder het groter (inter-)nationale kader uit het oog te verliezen.

Zoals al gezegd wordt veel aandacht besteed aan de boekdrukkunst (van Coster tot Johan Enschedé), maar bijvoorbeeld ook aan schilderkunst (uiteraard Frans Hals, maar ook Anton Mauve), wetenschap (de poging tot oprichting van een universiteit in de zestiende eeuw en een TU in de twintigste, maar ook successen als Nobelprijswinnaar Hendrik Antoon Lorentz), textielnijverheid (fabrikant Teyler), de aanleg van de eerste trekvaart en later de eerste spoorlijn van Nederland, van de oorsprong van de St. Bavo-verering, de vierjarige religievrede (zestiende eeuw) tot de jodenvervolging in de tweede wereldoorlog. Deze oorlog blijft in verhouding tot andere tijdvakken en zeker gezien zijn zwaarte onderbelicht. Vooral in de hoofdstukken over de politieke en sociaal-economische ontwikkelingen komt de oorlog er bekaaid af. Misschien is dit aan de hand van de titel Deugd boven geweld te verklaren, wellicht is daarom ook geen spoor terug te vinden van de Ripperda-kazerne, die van Haarlem eeuwenlang een garnizoenstad maakte.

Naast noten en een literatuurlijst is er een nuttige, overzichtelijk gerangschikte, beredeneerde bibliografie toegevoegd. Het boek wordt met een persoonsnamenregister afgesloten. Grote afwezige is een index naar onderwerp. Gezien de vele onderwerpen die in het boek behandeld worden, had deze lijst waarschijnlijk of onvolledig moeten blijven of had deze het boek onhandelbaar groot gemaakt.

\title{
Lianne Damen
}

H. A. J. Maassen, Tussen commercieel en sociaal krediet. De ontwikkeling van de Bank van Lening in Nederland van Lombard tot Gemeentelijke kredietbank 1260-I940 (Dissertatie Universiteit van Amsterdam 1993, Amsterdamse historische reeks. Grote serie XIX; Hilversum: Verloren, 1993, 329 blz., ISBN 906550390 0).

Maassen heeft na jarenlange studie een indrukwekkende dissertatie afgeleverd over een verschijnsel waar de gemiddelde burger zijn neus voor ophaalde. Kredietnemen was tot in onze eeuw niet altijd een teken van betrouwbaarheid, en zeker niet als dat gebeurde bij een bank van lening of, erger nog, pandjeshuis.

Het is de verdienste van Maassen dat hij, op basis van schitterend archiefspeurwerk, zo ongeveer alles wat over de lommerd in Nederland te vinden is op aangename en heldere wijze 
presenteert. Het begon allemaal in de dertiende eeuw toen Lombarden en anderen noordwaarts trokken om een gat in de markt te vullen door krediet te verlenen op basis van het belenen van onderpanden. Dat gebeurde per plaats, maar Maassen geeft ook voorbeelden van conglomeraten of families die meerdere plaatsen bedienden. Aanvankelijk voor iedereen, van hoog tot laag, maar al snel trad een verschuiving in de clientèle op naar de minder weigestelden. De hoge rentepercentages die de Lombarden vroegen, op jaarbasis $60 \%$ en hoger, veroorzaakten weerzin bij de leners. Die voelden zich gesteund door de kerk die officieel een renteverbod had uitgevaardigd. Uiteindelijk zou er in de Bourgondisch-Habsburgse tijd reglementering komen voor de lommerds. Daarvóór liepen de octrooien en pachtovereenkomsten die de stedelijke overheden verleenden sterk uiteen.

De Habsburgers wilden in hun streven naar centralisatie af van een machtige groep waar ze geen greep op kregen. De onafhankelijkheidsstrijd van de Republiek leidde tot een herwaardering van het verschijnsel. De kredietvraag in de zeeprovincies ontwikkelde zich krachtig en er ontstond zowaar heftige concurrentie tussen de banken. Dit droeg bij tot een geleidelijke daling van de rentestanden. De banken in de landprovincies echter bleven op de oude voet doorgaan. In de zeventiende eeuw maakte het Habsburgse centralisme plaats voor stedelijke autonomie. De stedelijke besturen hadden belang bij gezonde kredietvormen. Ze hechtten zo aan een plaatselijke kredietinstelling dat enkele steden de bankhouders zelf betaalden (200). De overheden konden er winst uit halen en het diende ook een sociaal doel, ten behoeve van de armen. Dat laatste aspect kreeg in de Bataafs-Franse tijd steeds meer nadruk en ook in het Koninkrijk zorgde de toenemende centralisatie voor nationale regelgeving, zoals met het fameuze Koninklijk Besluit van 1826: de banken werden bestempeld als instellingen van liefdadigheid met alle consequenties van dien. Zestig jaar later echter was een gerechtelijk vonnis er de oorzaak van dat overal pandhuizen ontstonden. Die pandhuizen zouden het kwade image van de lommerd voor geruime tijd bepalen. Via voorschotbanken, en geholpen door de stijgende welvaart, ontwikkelden de banken van lening zich uiteindelijk tot gerespecteerde gemeentelijke kredietbanken. Het boek besluit met een indrukwekkende lijst van archivalia en literatuur.

Het boek is veelomvattend, maar er is enige kritiek mogelijk. Uitvoerig is gekeken naar de politieke en juridische omstandigheden. Ook de sociale positie van de kredietnemers komt hier en daar ter sprake. Maar de auteur beperkt zich, zoals hijzelf in het voorwoord aangeeft, tot beschrijving en inventarisatie. Ik mis gegevens over omzetten bij de banken van lening. De financieel-economische achtergrond wordt te spaarzaam belicht. En daar moet toch wel het een en ander over te vermelden zijn. Frappant is dat uit de enkele grafiek (234) blijkt dat de omzetten van de kredietbanken in de depressie van de jaren dertig van deze eeuw snel inzakken.

Maassen komt eigenlijk niet toe aan een bespreking van het verschijnsel bank van lening in verband met andere banken of kredietverenigingen. Slechts de spaarbanken komen ter sprake. De economische analyse ontbreekt. Wellicht zou hierin voorzien kunnen worden door een micro-onderzoek van een of meerdere banken van lening ter hand te nemen. Dan zou er ook eens gekeken kunnen worden naar het feit waarom het juist buitenlanders of joden waren die zich al in de dertiende eeuw met geldzaken bezighielden. Stoorde de plaatselijke bevolking zich wel aan het renteverbod van de kerk, maar de eveneens katholieke Lombarden niet? Waar haalden lommerd of bank van lening het werkkapitaal vandaan? Zo kan er vanuit economisch standpunt nog het een en ander onderzocht worden, maar voor de historische component heeft Maassen het ultieme werk gedaan. Om zijn boek kan niemand, die zich met deze materie zou gaan bezighouden, nog heen.

Slechts een enkele onnauwkeurigheid: zo wordt (69) het concilie van 1310 te Vienne genoemd, 
terwijl dit acht bladzijden later in Wenen zou hebben plaatsgevonden. Vienne is toch echt een stad in Frankrijk en daar deden de kerkvorsten uitspraken over rente en woeker. De ' mysterieuze' term Cauwersinos (44) is volgens mijn encyclopedie afgeleid van de Franse stad Cahors, waaruit ook personen kwamen die zich met geldzaken bezighielden. Het zou tot slot mooi geweest zijn, als in de bijlagen, waar wel een gedicht van J. A. Holtrop uit 1870 is opgenomen, ook het lied tegen de woeker (245) dat Eduard Jacobs in 1912 ten gehore heeft gebracht, was vermeld. En waarom nergens de beroemdste werknemer van een lommerd genoemd? Bij deze dan: Joost van den Vondel.

N. A. van Horn

H. J. M. Claessen, A. H. Huussen jr., E. Ch. L. van der Vliet, Kolonisatie en staatsvorming buiten Europa (Ruggespraak. Historische Studies II; Groningen: Egbert Forsten, 1993, 148 blz., f30,-, ISBN 906890066 7).

Deze bundel van acht opstellen is de neerslag van een gelijknamige studiedag in Groningen, waaraan zowel door historici als sociale wetenschappers van verschillende pluimage werd deelgenomen. In de afzonderlijke bijdragen spelen daardoor verschillende concepties en benaderingen een rol. Centraal staat de vraag hoe Europese, koloniale contacten het ontstaan en de ontwikkeling van buiten-Europese staten hebben beïnvloed. Opmerkelijk genoeg ontbreekt hierbij het voor Nederlanders meest bekende voorbeeld: Indonesië.

Claessen vergelijkt de ontwikkelingen op Tahiti en Tonga na de komst van de westerlingen. In beide gevallen speelden zendelingen een grote rol, hoewel van hen een nederig optreden mocht worden verwacht, wisten zij zich in te dringen in de gunsten van de vorsten en zo de politieke ontwikkelingen mee te bepalen. De strijd tussen Engelsen, Fransen en Duitsers, handelaren, zendelingen, marinemensen en missionarissen compliceerde de ontwikkelingen, maar leidde in het geval van Tahiti tot Franse en op Tonga tot Engelse kolonisatie. Ondertussen was de staatsstructuur sterk veranderd.

Ook op Hawaii deden zich in dezelfde tijd vergelijkbare veranderingen voor, maar hier kregen de Amerikanen het uiteindelijk voor het zeggen. Hoewel daar een staat bestond heeft de komst van de westerlingen eveneens grote veranderingen gebracht. Als historicus heb ik moeite met de wijze waarop Van B rakel, de auteur van de bijdrage over Hawaii, een periode van vier eeuwen voorafgaand aan de westerse penetratie behandelt. Zonder veel commentaar wordt gesteld dat de structuur tot 1780 ongeveer dezelfde is gebleven, maar dat de veranderingen daarna tot 1820 voornamelijk door toedoen van een vorst tot stand waren gebracht. Welke redenen heb ik om aan te nemen dat nooit een andere vorst al eerder de zaak door elkaar heeft geschud? Mythen als verklaringsgrond hebben altijd een beperkte waarde.

De historicus 's Jacob behandelt op degelijke wijze de pogingen van de Nederlandse Oostindische Compagnie om in West-India, op de kust van Malabar, een krachtiger staatsstructuur aan te brengen om een peper export monopolie te kunnen vestigen. De sociale en politieke verhoudingen waren echter te gecompliceerd om dit mogelijk te maken.

F. Columbijn tracht in zijn bijdrage over Banten, een sultanaat in West-Java, 'historische data te ordenen met twee verschillende antropologische modellen' en de gevolgen van de Europese invloed te bepalen. Doordat hij aanneemt dat er over Banten geen nieuwe bronnen meer zijn aan te boren, quod non, is het meer een exercitie in modellen dan een bijdrage aan de geschiedbeoefening. Wat moeten we met zijn mededeling dat geschiedenis zonder modellen 'door eindeloze 